\title{
CORONA CELL DISPERSING PROPERTIES OF RABBIT TUBAL FLUID
}

\author{
LUIGI MASTROIANNI, JR. AND JAMSHID EHTESHAMZADEH \\ Department of Obstetrics and Gynecology, Harbor General Hospital, \\ Torrance, and University of California, Los Angeles, California, U.S.A.
}

(Received 10th April 1964)

\begin{abstract}
Summary. Exposure to tubal fluid in vitro causes loosening of the corona radiata of recently ovulated ova, pretreated with hyaluronidase. Incubation of ova in $0.05 \mathrm{ml}$ of fluid results in denudation of ova to the zona pellucida if mechanical agitation is provided by shaking with admixed sand. Control ova in Krebs-Ringer phosphate solution, Gey's solution, hyaluronidase or rabbit serum are unaltered under similar conditions. Both oestrous and postovulatory fluid are effective. The responsible factor is dialysable, heat-stable and survives lyophilization.
\end{abstract}

Motile spermatozoa, a suspension of killed spermatozoa, or sperm free fluid from the vas deferens cause dispersion in vitro of the cumulus cells of recently ovulated rabbit ova (Pincus \& Enzman, 1932). Swyer (1947) has produced rapid dispersion of the cumulus with a suspension of washed spermatozoa, the supernatant from dilute, centrifuged semen or hyaluronidase, but the inner layers of cumulus cells, the corona radiata, remain undisturbed, even after continued exposure for as long as $30 \mathrm{hr}$. When ova, so treated, are transferred to the oviduct of the oestrous rabbit, they are completely denuded within $3 \mathrm{hr}$. Since extracts of Fallopian tube failed to bring about dissociation of the corona radiata in vitro, Swyer concluded that mechanical, not chemical, factors were responsible for denudation of ova in vitro. The following experiments were designed to assess the influence of tubal secretions on the corona radiata.

Ova were flushed from the oviducts of adult New Zealand White rabbits with Krebs-Ringer phosphate solution $13 \frac{1}{2} \mathrm{hr}$ after an intravenous injection 500 i.u. of chorionic gonadotropin (generously supplied as A.P.L. by the Ayerst Company). The cumulus mass was dispersed by exposure to hyaluronidase for 15 to $20 \mathrm{~min}$ in a depression slide. Individual ova with their corona cells undisturbed were transferred to a parafilm-lined centre well of a small Warburg flask, two to three to each flask. The wells contained $0.2 \mathrm{ml}$ of rabbit tubal fluid, obtained by a means of a continuous collecting system (Clew \& Mastroianni, 1960) or calcium-free Krebs-Ringer phosphate solution with $\mathrm{pH}$ adjusted to that of fluid $(8 \cdot 2$ to $8 \cdot 4$. $)$. Incubation was carried out in air at $37^{\circ} \mathrm{C}$ for $4 \mathrm{hr}$. Ova were then transferred to a depression slide for study with the phase- 
contrast microscope and photography. In preliminary experiments an occasional ovum was denuded in tubal fluid. More often, the corona cells appeared loosened but were not separated from the zona pellucida. Ova in KrebsRinger phosphate solution were almost invariably unaltered. In an attempt to establish a more discrete end point, $30 \mathrm{mg}$ of fine sand were added to some flasks to provide a 'mechanical' factor. Flasks without sand were run simultaneously (Table 1, Series A). A few ova in the flasks containing sand were denuded, but this effect was inconstant. Control ova in Krebs-Ringer phosphate solution with sand were essentially unchanged. The corona cells of the undenuded ova in tubal fluid often appeared loosened, but this change was difficult to evaluate objectively.

TABLE 1

IN-VITRO EFFECT OF TUBAL FLUID ON THE CORONA RADIATA

\begin{tabular}{|c|c|c|c|c|c|c|c|c|c|c|c|c|c|}
\hline \multirow{3}{*}{ Series* } & \multirow{3}{*}{$\begin{array}{c}\text { No. } \\
\text { experiments }\end{array}$} & \multicolumn{12}{|c|}{ No. ova } \\
\hline & & \multicolumn{4}{|c|}{ Fluid with sand } & \multicolumn{4}{|c|}{ Fluid without sand } & \multicolumn{4}{|c|}{ Control with sand } \\
\hline & & d & $\mathrm{pd}$ & 1 & $\mathrm{u}$ & d & $\mathrm{pd}$ & 1 & & d & pd & 1 & $\mathbf{u}$ \\
\hline $\begin{array}{l}\text { A } \\
\text { B } \\
\text { C } \\
\text { D } \\
\text { E } \\
\mathbf{F}\end{array}$ & $\begin{array}{r}12 \\
8 \\
46 \\
10 \\
4 \\
6\end{array}$ & $\begin{array}{r}7 \\
15 \\
115 \\
20 \\
10 \\
9\end{array}$ & $\begin{array}{l}4 \\
0 \\
7 \\
1 \\
0 \\
6\end{array}$ & $\begin{array}{l}7 \\
- \\
- \\
- \\
-\end{array}$ & $\begin{array}{r}12 \\
3 \\
13 \\
4 \\
0 \\
2\end{array}$ & $\begin{array}{l}0 \\
7\end{array}$ & $\begin{array}{l}2 \\
3\end{array}$ & $\begin{array}{l}5 \\
-\end{array}$ & $\begin{array}{l}5 \\
8\end{array}$ & $\begin{array}{l}1 \\
1 \\
1 \\
0 \\
0 \\
0\end{array}$ & $\begin{array}{l}0 \\
2 \\
1 \\
0 \\
0 \\
1\end{array}$ & $\begin{array}{l}1 \\
- \\
- \\
- \\
-\end{array}$ & $\begin{array}{r}17 \\
15 \\
111 \\
20 \\
8 \\
22\end{array}$ \\
\hline
\end{tabular}

* A- $-0.2 \mathrm{ml}$ oestrous fluid, collected by continuous cannulation method. Control: Krebs-Ringer phosphate. $B-0.05 \mathrm{ml}$ oestrous tubal fluid collected by ligation. Control: Krebs-Ringer phosphate. $\mathrm{C}-0.05 \mathrm{ml}$ postovulatory fluid collected by ligation. Control: Gey's solution. D- 0.05 ml phostovulatory fluid collected by ligation, boiled for $2 \mathrm{~min}$. Control: Gey's solution. E- $-0.05 \mathrm{ml}$ of oestrous fluid collected by ligation, heated for $30 \mathrm{~min}$ at $98^{\circ} \mathrm{C}$, reconstituted to volume with distilled water. Control: Gey's solution. F- $0.05 \mathrm{ml}$ fluid, lyophilized and reconstituted to volume with distilled water. Control: Gey's solution.

Because the tubal fluid used in the above experiments had been collected in an external chamber over many hours, the possibility of alterations in the quality of the fluid either from bacterial contamination or from prolonged storage could not be excluded. In all subsequent experiments, fluid was collected by ligating the oviduct just proximal to the fimbria and at the uterotubal junction. The fluid which accumulated between the ligatures was aspirated from the oviduct at laparotomy 24 to $36 \mathrm{hr}$ later. At the $0.2 \mathrm{ml}$ volume, it appeared that ova floated on the surface of the fluid and were not always exposed to the mechanical effect of the sand. Accordingly, the amount of fluid in each flask was reduced to $0.05 \mathrm{ml}$. Gey's solution, being a more completely balanced tissue culture medium, was substituted for Krebs-Ringer phosphate solution as a control, the $\mathrm{pH}$ being adjusted to that of tubal fluid for each experiment. A standard incubation time of $2 \mathrm{hr}$ was used. The other experimental conditions were unaltered. At 
the completion of each experiment, eggs were described as denuded, partially denuded, or unchanged. Ova were characterized as unchanged unless at least some of the zona was entirely free of corona cells. These modifications of the experimental design resulted in denudation of the majority of ova incubated with sand in oestrous tubal fluid (Series B) and in fluid from animals ovulated $36 \mathrm{hr}$ previously with intravenous chorionic gonadotropin (Series C). In the absence of sand, denudation was obtained less consistently. Ova in the control flasks, with rare exceptions, remained unchanged.

Boiling for a few moments (Series D) or heating for $30 \mathrm{~min}$ at $98^{\circ} \mathrm{C}$ (Series E) did not materially affect the ability of the fluid to disperse corona cells. Activity was retained after lyophilization and reconstitution to volume with distilled water (Series F). To investigate the possibility that the denudation phenomenon might have been brought about by traces of hyaluronidase transferred initially with the ova, incubation was carried out in Gey's solution containing hyaluronidase, $300 \mathrm{i} . \mathrm{u} . / \mathrm{ml}$. In five experiments, all eleven ova used remained unaltered after $4 \mathrm{hr}$ of incubation in flasks containing $0.05 \mathrm{ml}$ of hyaluronidase solution with sand. Fluid was dialysed against normal saline for $2 \mathrm{hr}$ and ova were incubated with sand in both solute and dialysate. In twenty-one separate experiments, thirty-eight of sixty ova were denuded in the solute and thirty-eight of fifty-seven in the dialysate. In six experiments, fifteen ova were incubated in flasks containing $0.05 \mathrm{ml}$ of fresh serum from the donor animals and sand; in thirteen, the corona radiata remained unaltered, while eleven of eleven ova from the same donors, incubated simultaneously in tubal fluid, were denuded.

Tubal fluid is capable of loosening the densely arranged corona radiata cells which surround recently ovulated ova in the rabbit. Denudation of ova to the zona pellucida can then be brought about by mechanical action. The activity of the fluid is not destroyed by heating or lyophilization and is observed in both solute and dialysate following dialysis against saline.

This work was supported by Grant TI 4D31 from the National Institute of Child Health and Human Development, U.S.P.H.S.

\section{REFERENCES}

Clewe, T. H. \& Mastroianni, L. (1960) A method for continuous volumetric collection of oviduct secretions. F. Reprod. Fertil. 1, 146.

Pincus, G. \& Enzman, E. (1932) Fertilization in the rabbit. 7. exp. Biol. 9, 403.

SwYrR, G. I. M. (1947) A tubal factor concerned in denudation of rabbit ova. Nature, Lond. 159, 873. 